ISSN 0975-3311

Ushus JBMgt, 9, 2 (2010) 50-58

ISSN 0975-3311 | https://doi.org/10.12725/ujbm.17.4

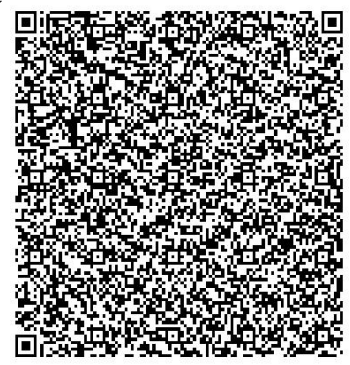

\title{
A SECTOR WISE INFLUENCE OF EQUITY OWNERSHIP HOLDING ON THE CORPORATE DEBT POLICY- AN
} EMPIRICAL ANALYSIS

\author{
R. Shunmughan* \& E.P. Sengottuvel**
}

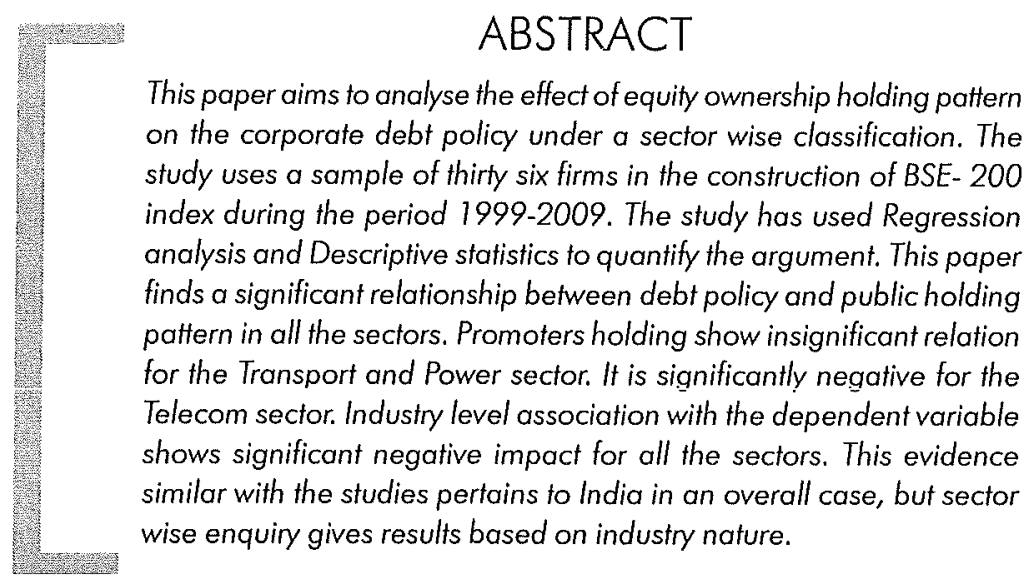

* Dept. of Commerce, Gobi Arts \& Science College, Gobichettipalayam - 638452. E-mail: shanmuganarul@gmail.com

* Dept. of Commerce, Gobi Arts \& Science College, Gobichettipalayam - 638452. E-mail: epsvel@gmail.com 


\section{Introduction}

Corporate sector represents a vast portion of contribution in the economy due to favorable policy in many developing countries even in India. The increased entrant of corporate model in different sector can encourage the competition and need for adoption of best debt- equity mix where economics of finance arises. Mira (2005) points out that one of the areas of financial economy that has greatly worried academicians and professionals is debt policy decision in companies. Psillaki (2009) argues that corporate financing decision is a complex process and existing theories can at best explain only facets of the diversity and complexity of financing decisions. India introduced many market oriented reforms in their financial sectors since the mid eighties and early nineties. This has led to a substantial transformation of the institutional setup with in which firms have operated giving more flexibility to the Indian financial manger in choosing the capital structure of the firm Bhaduri (2002). Friend and Lang (1988) study the result of managerial self interest in determining the level of corporate debt- equity mix. Jensen and Meckling (1976) points out that if ownership holdings are widespread in nature, which results in less commanding power of shareholders that paves the way of rising of agency problem and supports Leverage might be a solution to overcome from the agency problem. Lin and Young (2008) mention that the relationship between ownership holding pattern and firm characteristics has received considerable attention and it is because of a failure to reach a consensus regarding the nature of the relationship.

In developed world, there are studies related to holding pattern and debt policy but it is limited in count pertains to developing world and sector wise enquiry in very minimum in count. The existing research work in debt policy pertains to India mentions different factors such as Asset Structure, Profitability, and Risk etc., as the influencing factors of corporate debt policy. This work is trying to quantify the impact of ownership holding on debt policy in particular sector wise. In depth enquiry in to the different industry gives new results to existing one due to prevailing of divergent characteristics.

\section{Review of related studies}

Saumitra N.Bhaduri (2002) attempts to study the corporate borrowing behavior of developing countries through a case study of the Indian corporate sector. He shows that the corporate borrowing behavior is influenced by factors such as Growth, Cash flow, Size, product and industry 
characteristics. The main objective of their study is to analyze various measure of debt depending on the maturity structure. In order to validate his argument, he employs confirmatory factor analysis technique to measure unobserved or latent variables. His findings pointed out both the agency theoretic and information based models of capital structure that can successfully predict the corporate borrowing behavior in the sample.

Friend I and Larry Lang (1988) study the management and ownership holing effect in framing debt- equity mix decisions. These paper choose the sample of 984 NYSE (New York Stock Exchange) firms from 1979 to 1983. They use econometric analysis such as Descriptive Statistics, Correlation, and Regression to confirm the argument. The findings of the study shown that the management's stake holding negatively related to the debt ratio due to non diversifiable risk of debt to management. If the particular company has majority of public investors then the average debt ratio is significantly higher than the firm which has more managerial principal stake holders.

Berger and Yermack (1997) examine the connection between managerial entrenchment and Debt Equity mix. Their paper checks whether the degree of this entrenchment have impact Firms choices about capital structure. Their main aim is to reveal whether significant associations exist between patterns of firm leverage and variables that are related with managerial entrenchment. They evidence that Leverage is lower when the CEO has a long tenure in office and does not face strong monitoring from the board and major stake holders.

Jong. A and Veld .C (2001) empirically scrutinize the incremental capital structure decisions under managerial entrenchment. They study about the factors which induce Dutch companies to issue either stocks or bonds. To ensure their word, they make use of Logic regression, moral hazard and adverse selection model. These mode!s are tested on a sample of 110 issued of public and private seasonal equity and 137 public issues of straight debt. They looked at the motives of the company to choose equity for debt and measure the wealth effects of these security issues. They conclude that the moral hazard is relevant for Dutch firms because managers likely to have discretionary space to overinvest. This behavior would be reflected in the Debt-Equity choice but the shareholders valuation will be shown in the announcement effects. 


\section{Objective of the study}

To analyse the sector wise impact of equity holding pattern on the debt policy of a company.

\section{Data and sample}

The sample is based on the financial information provided by the CMIE Prowess 3.1 Database and audited financial results of the companies that consist of financial information of BSE 100 listed Companies. This work focused on three important sectors such as Transport, Telecom and Power companies listed in BSE-100 in Bombay Stock Exchange.

\section{Model specification and variable description}

Regression analysis is applied to find out the impact of different holding pattern on leverage and serial correlation level is checked by applying Durbin Watson statistics. In this research work the following model has created.

$\mathrm{DTPO}_{\mathrm{it}}=\alpha+\beta_{1} \mathrm{NF}_{\mathrm{it}}+\beta_{2} \mathrm{SIZE}_{\mathrm{it}}+\beta_{3} \mathrm{ROA}_{\mathrm{it}}+\beta_{4} \mathrm{RISK}_{\mathrm{it}}+\beta_{5} \mathrm{PRO}_{\mathrm{it}}+\beta_{6} \mathrm{PUB}_{\mathrm{it}}+\mu$

NF : Ratio of net property, plant and equipment to book assets

SIZE : Log of total assets

DTPO : Debt/Asset ratio

ROA : Mean of earnings / asset ratio

RISK : S.D of earnings / asset ratio

PRO : Market Value of equity held by promoters

PUB : Market Value of equity held by public

\section{Definition and Measurement of Variables}

To calculate the leverage level of companies' debt to value ratio that means debt divided by total value of book assets which is defined on a book value basis excluding trade credit and short term accruals from debt Friend and Lang (1988); Rajan and Zingles (1995); and Lin (2008). To measure the ownership holdings of companies, promoters' holdings of shares, and non promoters or public holdings of equity is used Dwiredi 
and Jain (2005). To find out market value of equity we multiplying the holdings by the closing stock price of the particular year.

To evaluate the profitability of companies mean of earnings before interests and Taxes divided by assets on a book value basis would taken as a reasonable proxy for measuring the profitability of a firm Demsetz and Lehn (1985). Standard deviation of earnings divided by assets on a book value basis is taken as a proxy for Risk Friend and Lang (1988).

Logarithm of total assets as a proxy for size of the company and the Asset structure which is calculated by dividing net fixed assets to total book assets is treated as asset structure of a firm Friend and Lang (1988).

\section{Results and Interpretation}

Table 1 discloses about the descriptive statistics for the three different sectors. The mean ratio for Asset structure is comparatively higher for the Power sector companies than Telecom and Transport in the selected sample which proves that power sector focuses more on establishment of fixed assets in their income generating activities.

It is noted that the debt ratio is comparatively higher for the Telecom sector than other two sectors in the selected sample. Telecom sector might be having favorable environment to use debt in their capital mix and it is deviated in a meager way for the companies are under the power sector.

Table-1: Descriptive Statistics

\begin{tabular}{|l|c|c|c|c|c|c|}
\hline sectors & \multicolumn{2}{|c|}{ Transport } & \multicolumn{2}{c|}{ Telecom } & \multicolumn{2}{c|}{ Power } \\
\hline Variables & Mean & S.D & Mean & S.D & Mean & S.D \\
\hline NF & 0.317 & 0.096 & 0.276 & 0.216 & 0.357 & 0.102 \\
SIZE & 3.401 & 0.354 & 3.047 & 0.810 & 3.689 & 0.160 \\
DTPO & 0.213 & 0.121 & 0.247 & 0.199 & 0.264 & 0.069 \\
ROA & 0.110 & 0.062 & 0.087 & 0.072 & 0.072 & 0.029 \\
RISK & 0.034 & 0.023 & 0.028 & 0.026 & 0.012 & 0.007 \\
PRO & 5.373 & 0.730 & 5.689 & 0.673 & 5.396 & 0.384 \\
PUB & 4.957 & 0.953 & 5.048 & 0.716 & 5.239 & 0.415 \\
\hline
\end{tabular}

- Description of the variables: NF: Ratio of net property, plant and equipment to book assets; SIZE: Log of total assets; LEV: Debt/Asset ratio; PROFIT: Mean of earnings / asset ratio; RISK: S.D of earnings / asset ratio; MPO: Market Value of equity held by promoters; PUB: Market Value of equity held by public. These descriptions are same for following tables. 
Size factor is measured by total assets is comparatively higher for the Power sector where fixed assets level is also high. Profitability ratio of Transport sector shows higher mean level than the remaining two sectors and its observed deviation is lesser for the Power sector where is the profit level involves in constant level change. Risk level of firm is comparatively lower for the Power sector and higher level fluctuation is observed from our selected sample for the Transport sector. Maximum level of deviation in equity ownership holding variable is observed in the Transport sector and minimum level noted in the Power sector.

Table - 2 Multiple Regression Estimates for the selected Sample

\begin{tabular}{|l|c|c|c|c|c|c|}
\hline sectors & \multicolumn{2}{|c|}{ Transport } & \multicolumn{2}{c|}{ Telecom } & \multicolumn{2}{c|}{ Power } \\
\hline & Beta & $t,(p)$-value & Beta & $t,(p)$-value & Beta & $t,(p)$-value \\
\hline AS & 0.528 & $2.41^{* *}(0.020)$ & -0.772 & $2.738^{* *}(0.011)$ & -0.679 & $-2.644^{* *}(0.023)$ \\
SIZE & 0.484 & $3.25^{*}(0.002)$ & 1.014 & $3.168^{*}(0.004)$ & 0.437 & $1.920(0.081)$ \\
ROAM & -0.507 & $-2.46^{* *}(0.018)$ & -0.306 & $-1.248(0.222)$ & -0.239 & $-1.177(0.264)$ \\
ROAS & -2.132 & $-4.30^{*}(0.000)$ & -0.187 & $-0.703(0.488)$ & -0.184 & $-1.046(0.318)$ \\
PMV & -0.025 & $-0.08(0.934)$ & -1.043 & $-3.576^{*}(0.001)$ & 0.674 & $0.814(0.433)$ \\
NPMV & -0.194 & $-2.76^{*}(0.008)$ & 0.836 & $2.725^{* *}(0.011)$ & -1.636 & $-2.090^{* *}(0.061)$ \\
\hline
\end{tabular}

Industry dummies

\begin{tabular}{|l|r|r|r|r|r|r|}
\hline Transport & & $-0.271(-5.27)^{*}$ & & & \\
Telecom & & & & $-0.438(-4.29)^{*}$ & & \\
Power & & & & & $-0.138(-2.36)^{* *}$ \\
R2 & 0.656 & & 0.513 & & 0.751 & \\
Adi R2 & 0.613 & & 0.409 & & 0.615 & \\
F (p) & 14.963 & & & $4.925(0.001)$ & & $5.53(0.007)$ \\
& $(0.000)$ & & & & & \\
D.W & 1.769 & & 1.564 & & 1.879 & \\
\hline
\end{tabular}

**Regression is significant at 0.05 level

*Regression is significant at 0.01 level 
In that Table - 2, Net Fixed assets shows significant positive relation with the borrowing level in the case of Transport sector and is negative for the Telecom and Power sectors. Since net fixed asset is considered as collateral for using the debt in the capital mix Rajan and Zingles (1995) is consistent in the Transport sector and inconsistency of results obtained for the remaining two sectors. It is noted from our empirical model that the Size of the firm has positive influence with the dependent variable in significant way for all the sectors. Large firms may be more diversified and to be more leveraged is consistent with the existing empirical works Bhaduri (2002). ROA shows significant negative outcome in the case of Transport sector and it is insignificant in the case of Telecom and Power sectors. Excess profit may be used in the place of debt to the firms need. Risk level of firm shows significant negative influence with the leverage level due to its fixed cost bearing nature and statistically insignificant for the Telecom and Power sectors. From the outcome of the empirical investigation it is found that the ownership holding of Promoters shows significant negative impact with the borrowing level of the firm in the telecom sector and statistically insignificant for the remaining sectors. There might be the presence of the threat of Bankruptcy for the promoters in using fixed cost bearing instruments in their Debt - Equity mix decisions. Holding of Public which mainly comprises of Institutional participation shows significant negative association in the case of Transport and Power sector and it is positive in the case of Telecom sector where might be the anti takeover threat prevails. It is consistent with the argument that the takeover threat can encourages to use debt in their capital structure Muller (2008). Industry level association with the dependent variable shows significant negative impact for all the sectors. Serial auto correlation level is checked with the Durbin Watson statistics for our selected sample.

Table 2 shows that the Mulliple Regression equation was found statistically a good fit as Adj $R^{2}$ is 0.613 for Transport Sector; it is 0.409 for Telecom and 0.615 for the power sector. It shows that the six independent variables in each model contribute about $50 \%$ of variation in dependent variable and ' $F$ ' statistics shows that this was statistically significant at $1 \%$ level. 


\section{Conclusion}

This empirical paper studies about the influence of equity holding pattern on the corporate debt policy for the Transport, Telecom and for Power sector. This paper finds a significant relationship between debt policy and public holding pattern in all the sectors. Promoters holding show insignificant relation for the Transport and Power sector. It is significantly negative for the Telecom sector. The above results has taken from the regression model after controlling of firm characteristics such as Business risk, Size of the firm, Net Fixed assets and firm profitability. This evidence discloses that the public share holding is negative attitude to use the debt in many cases where trading on equity is in absence mode and it is irreversible in the case of telecom industry. Further research may be fruitful by applying different measures of debt policy to get the more exact findings.

\section{References}

1. Bhaduri .N (2002) "Determinants of Corporate Borrowing: Some Evidence from Indian Corporate Structure", Journal of Economics and Finance, Vol (26) 2, 200-215.

2. Demsetz, H. and Lehn, K. (1985), "The Structure of Corporate Ownership: Causes Consequences", Journal of Political Economy, Vol (93) 6, 1155-1177.

3. Dwivedi, N. and Jain A.K., (2005), "Corporate Governance and Performance of Indian Firms: The Effect of Board Size and Ownership, Employee Responsibilities and Rights Journal, Vol (17) 3, $161-172$.

4. Ferri .M.G and Jones W.H (1979), "Determinants of Financial Structure - A New Methodology Approach", Journal of Finance, Vol (34) 3, 631-632.

5. Friend .I and Lang H.P (1988) "An Empirical Test of the Impact of Managerial Self Interest on Corporate Capital Structure ", Journal of Finance, (43) (2), pp. 271-281.

6. Jensen M. and Meckling W. (1976), "Theory of the Firm: Managerial Behavior, Agency Costs and Ownership Structure", Joumal of Financial Economics, 3, 305-36́0

7. Jong .A and Veld .C (2001) "An Empirical Analysis of Incremental Capital Structure Decisions under Managerial Entrenchment", Journal of Banking and Finance, (25), pp. 1857-1895.

8. Lin and Huang (2008), "An Empirical Study on the Relationship between Ownership and Firm Performance: Taiwan Evidence", Afro Asian J. Finance and Accounting, 1(1). 
9. Margaritis, D. and Psillaki, M (2009), "Capital Structure, Equity Ownership and Firm Performance", Journal Of Banking And Finance, Article In Press.

10. Mueller .E (2008) "Benefits of Control, Capital Structure and Company Growth", Applied Economics, (40), pp.2721-2734.

11. Rajan R. and Zingles L., (1995), "What Do We Know about Capital Structure? Some Evidence from International Data, Journal of Finance, 50, 236-292.

12. Suresh Babu and Jain (1998) "Capital Structure of Indian Multinational Corporations", South Asian Journal of Management, (3) (3), 74-76. 